\title{
Variability of water mass properties in the Strait of Sicily in summer period of 1998-2013
}

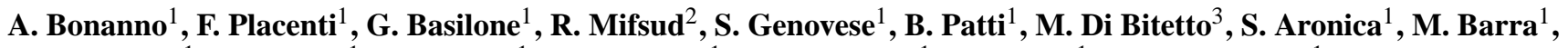 \\ G. Giacalone ${ }^{1}$, R. Ferreri ${ }^{1}$, I. Fontana ${ }^{1}$, G. Buscaino ${ }^{1}$, G. Tranchida ${ }^{1}$, E. Quinci ${ }^{1}$, and S. Mazzola ${ }^{1}$ \\ ${ }^{1}$ Istituto per l'Ambiente Marino Costiero (IAMC) of the Consiglio Nazionale delle Ricerche (CNR), Detached Units of \\ Capo Granitola (TP), Naples and Mazara del Vallo (TP), Italy \\ ${ }^{2}$ Ministry for Resources and Rural Affairs (MRRA), Fort San Lucjan, Malta \\ ${ }^{3}$ Consiglio Nazionale delle Ricerche (CNR), P.le A. Moro, 7-00185, Rome, Italy \\ Correspondence to: F. Placenti (francesco.placenti@iamc.cnr.it)
}

Received: 27 January 2014 - Published in Ocean Sci. Discuss.: 13 March 2014

Revised: 14 August 2014 - Accepted: 29 August 2014 - Published: 2 October 2014

\begin{abstract}
The Strait of Sicily plays a crucial role in determining the water-mass exchanges and related properties between the western and eastern Mediterranean. Hydrographic measurements carried out from 1998 to 2013 allowed the identification of the main water masses present in the Strait of Sicily: a surface layer composed of Atlantic water (AW) flowing eastward, intermediate and deep layers mainly composed of Levantine intermediate water (LIW), and transitional eastern Mediterranean deep water (tEMDW) flowing in the opposite direction. Furthermore, for the first time, the signature of intermittent presence of western intermediate water (WIW) is also highlighted in the northwestern part of the study area $\left(12.235^{\circ} \mathrm{E}, 37.705^{\circ} \mathrm{N}\right)$.

The excellent area coverage allowed to highlight the high horizontal and vertical inter-annual variability affecting the study area and also to recognize the permanent character of the main mesoscale phenomena present in the surface water layer.

Moreover, strong temperature-salinity correlations in the intermediate layer, for specific time intervals, seem to be linked to the reversal of surface circulation in the central Ionian Sea.

The analysis of CTD data in deeper water layer indicates the presence of a large volume of tEMDW in the Strait of Sicily during the summers of 2006 and 2009.
\end{abstract}

\section{Introduction}

The Strait of Sicily is a topographically complex region of the central Mediterranean (CMED) comprising two sills separated by an internal deep basin; the eastern sill has a maximum depth of about $540 \mathrm{~m}$, and the western one is composed of two narrow passages with a maximum depth of $530 \mathrm{~m}$. The central basin has trenches that are more than $1700 \mathrm{~m}$ deep (Gasparini et al., 2005). From a dynamic point of view, three main spatial and temporal scales characterize the CMED (Sorgente et al., 2011): (i) the mesoscale (characterized by horizontal scale less than a few tens of kilometres and periods in the range from a few days to a few tens of days), (ii) the large Mediterranean Basin scale including the thermohaline circulation, and (iii) the sub-basin scale (oceanographic phenomena characterized by diameters ranging between 200 and $300 \mathrm{~km}$ ). The mesoscale structures, (i), under the influence of wind stress, topography and internal dynamical processes generate boundary currents and jets, which can bifurcate, meander and grow, then forming ring vortices and filament patterns interacting with the large-scale flow fields (Lermusiaux, 1999; Lermusiaux and Robinson, 2001). The thermohaline circulation (ii) in this area is anti-estuarine and is mainly driven by the balance between the relatively fresh waters entering at the Gibraltar Strait and the negative fresh-water budgets over the whole Mediterranean Basin (Sorgente et al., 2011). Specifically, the upper open conveyor belt consists of an eastward flow of low-salinity Atlantic water (AW) and an intermediate layer $(200-500 \mathrm{~m})$ of westward-spreading 
saltier Levantine intermediate water (LIW), enriched by Cretan intermediate water (CIW). Two quasi-closed secondary cells are present in the eastern and in the western Mediterranean Basins, which are responsible for the transformation of surface and intermediate waters into eastern and western Mediterranean deep waters (EMDW and WMDW), respectively. The role of the LIW is particularly important since it is the preconditioning agent for the formation of both the Adriatic deep water (AdDW) and WMDW (Gačić et al., 2013). At sub-basin level (iii), two main veins of the AW are known to flow in the Strait of Sicily: the Atlantic Tunisian Current (ATC) (Sammari et al., 1999) in the south along the African coast, and the Atlantic Ionian Stream (AIS) (Robinson et al., 1999) in the north along the Sicilian coast. The AIS constitutes an energetic current mainly flowing eastward, able to force upwelling on the Adventure Bank (AB) (Fig. 1) and along the southern Sicilian coast, especially during summer, when such current is stronger. An important spatial variability exists in terms of shape, position and strength of permanent or quasi-permanent sub-basin gyres and their unstable lobes, meanders patterns, bifurcation structures and strength of permanent jets, transient eddies and filaments (Robinson et al.,1999; Sorgente et al., 2011; Basilone et al., 2013; Bonanno et al., 2013). The ATC, flowing along the Tunisian coast, shows a more clearly-marked path in winter (Sorgente et al., 2003, 2011; Béranger et al., 2004) than in summer. Further confirmation of the weakening of the ATC signal in summer is highlighted by Placenti et al. (2013), who found a more regular jet of the AIS than the ATC, which becomes unstable, also producing small-scale features (Gasparini et al., 2008). The intermediate and deep circulations in the Strait of Sicily are mainly represented by the intermediate water of eastern origin, moving westwards around the submarine mountains of the eastern Mediterranean before crossing the channel through the sills, south of Malta, at a depth ranging from 250 to $350 \mathrm{~m}$ (Placenti et al., 2013; Lermusiaux and Robinson, 2001). Interannual changes have been recorded in the outflowing dense-water-mass characteristics in the Sicily Channel (Gasparini et al., 2005).

The classical view of a quasi-stable thermohaline circulation of the Mediterranean has recently been overruled. During the 1990s, deep water formed in the Aegean Sea replaced that formed in the Adriatic. Huge amounts of dense waters characterized by enhanced salinity and temperature were released for a few years, forming the eastern Mediterranean Transient (EMT) (Roether et al., 2007; Theocharis et al., 2002), significantly influencing the thermohaline structure and stratification of the entire eastern Basin (Borzelli et al., 2009; Gačić et al., 2013). The EMT-induced changes have been communicated through the Strait of Sicily to the western Mediterranean Basin (Gasparini et al., 2005). A significant warming and salinification of the whole water column has also been observed in the western Mediterranean, comparable to the EMT, both in terms of intensity and observed effects (Schroeder et al., 2008). Furthermore, it has
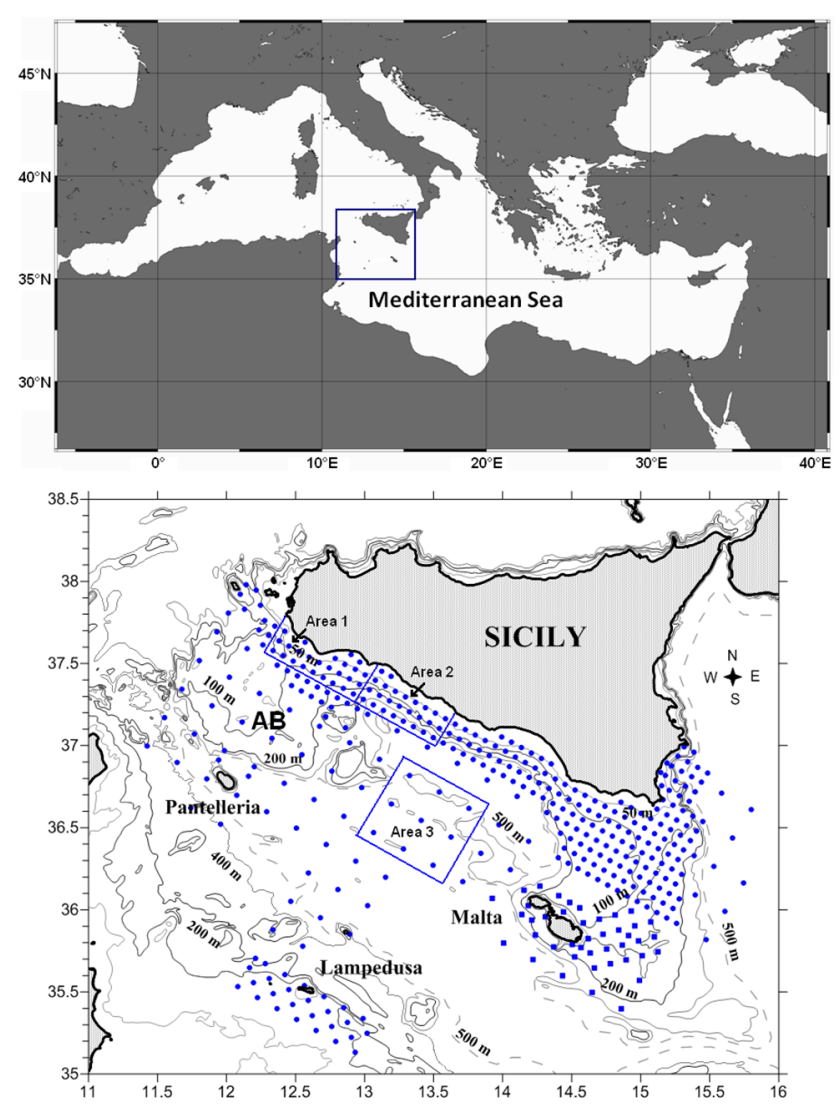

Figure 1. The study area in the Strait of Sicily and the overall sampling design adopted in the period 1998-2013 (blue dots); the Maltese waters are investigated since 2004 (blue squares). Upwelling areas (1 and 2) and the control area (3) are identified by three rectangles.

been demonstrated that the upper-layer circulation in the Ionian (Borzelli et al., 2009; Gačić et al., 2010), the thermohaline properties of the AdDW (Gačić et al., 2010) and the salt distribution over the EM (Gačić et al., 2011) are interconnected through the Bimodal Oscillating System (BiOS) (Gačić et al., 2010). In fact, during the last 25 years, it has been observed that the upper-layer circulation in the Ionian reversed on decadal time scales, from anticyclonic to cyclonic, and vice versa. In particular, the anticyclonic mode represents a preconditioning mechanism for the dense-waterformation processes in the Aegean and eventually for EMTlike events (Demirov and Pinardi, 2002; Gačić et al., 2011). In this context, the Strait of Sicily is the most suitable region for observing the exchanges between the two basins and, more specifically, for following how hydrographic modifications produced in one sub-basin can propagate into the other one (Gasparini et al., 2005).

The main aim of this study is to examine the variability of thermohaline properties of the water masses flowing through the Strait of Sicily in summer during the period 1998-2013. Furthermore, the available data set permitted evaluation of 
the permanent character of the main mesoscale circulation structures in the area. The entire time series is analysed both in terms of horizontal and vertical spatial variability, and may improve the understanding of long-term variability and evolution of the Mediterranean circulation. The document also provides contributions that may allow the modellers to assess the performance of hydrological models of this area.

\section{Data set and methods}

The data set analysed here has been acquired over 16 oceanographic surveys carried out during the period 1998-2013 (Table 1) on board the R/V Urania in the Strait of Sicily. Sampling stations are arranged on a regular grid of 4 nautical miles in inshore waters and 12 miles in offshore waters, to ensure maximum area coverage with specific attention to the continental shelf along the southern coast of Sicily (Fig. 1). Since 2004, CTD profiles have also been collected in the Maltese waters in the framework of the FAO MedSudMed Project "Assessment and monitoring of the fishery resources and the ecosystems in the Straits of Sicily" (http://www.faomedsudmed.org/). The sampling design in Fig. 1 shows the maximum area coverage in the Strait of Sicily; during some of the surveys, such design was modified, mainly due to bad weather conditions. The long-term variability in the hydrological characteristics of the Strait of Sicily has been analysed on the basis of vertical profiles of temperature $\left({ }^{\circ} \mathrm{C}\right)$ and salinity obtained from the surface to the bottom by means of a CTD-rosette system. This consisted of a CTD SBE 911 plus probe and a General Oceanics rosette, equipped with $2412 \mathrm{~L}$ Niskin Bottles. The probes were calibrated before and after the cruise at CMRE (NATO Centre for Maritime Research and Experimentation) in La Spezia, Italy. The collected downcast data were quality-checked and processed in agreement with the Mediterranean and ocean database instructions (Brankart, 1994), using the SeasoftWin32 software. The overall accuracies are within $0.001{ }^{\circ} \mathrm{C}$ for temperature, $0.001 \mathrm{~s} \mathrm{~m}^{-1}$ for conductivity, and $0.015 \%$ of full scale for pressure. With the aim of characterizing water masses and their inter-annual variability, we divided the water column into three layers. Two of them - the surface (0-200 m) and the intermediate $(200-500 \mathrm{~m})$ layers - represent the two main water masses in the Strait of Sicily; a third layer $(>500 \mathrm{~m})$ is considered for characterizing deeper water mass. Mean values of temperature, salinity and density (and SD in Table 2) are evaluated for the area with longitude in the range $11.5-15^{\circ} \mathrm{E}$ and latitude in the range $35-38^{\circ} \mathrm{N}$. In the same area, mean values of salinity minimum $\left(S_{\min }\right)$ and salinity maximum $\left(S_{\max }\right)$, as well as mean potential temperature and mean depth at the salinity minimum and salinity maximum, are estimated.

Three specific sub-areas have been identified in the study area to highlight the effects of coastal upwelling on the temperature and salinity fields, and to verify the persistence of
Table 1. Sampling period and name of the oceanographic surveys carried out in the Strait of Sicily.

\begin{tabular}{ll}
\hline Date mm/yyyy & Cruise name \\
\hline $23 / 06 / 1998-13 / 07 / 1998$ & Mago98 \\
14/10/1999-29/10/1999 & Juvenile99 \\
$24 / 06 / 2000-11 / 07 / 2000$ & Ansic00 \\
$05 / 07 / 2001-26 / 07 / 2001$ & Ansic01 \\
10/07/2002-01/08/2002 & Ansic02 \\
10/07/2003-04/08/2003 & Ansic03 \\
17/06/2004-08/07/2004 & Ansic04 \\
$06 / 07 / 2005-25 / 07 / 2005$ & Bansic05 \\
$29 / 07 / 2006-11 / 08 / 2006$ & Bansic06 \\
$28 / 06 / 2007-17 / 07 / 2007$ & Bansic07 \\
$25 / 06 / 2008-14 / 07 / 2008$ & Bansic08 \\
03/07/2009-22/07/2009 & Bansic09 \\
$25 / 06 / 2010-14 / 07 / 2010$ & Bansic10 \\
$08 / 07 / 2011-26 / 07 / 2011$ & Bansic11 \\
$04 / 07 / 2012-23 / 07 / 2012$ & Bansic12 \\
26/06/2013-16/07/2013 & Bansic13 \\
\hline
\end{tabular}

this phenomenon. In particular, areas 1 and 2 in Fig. 1 are those in which the phenomenon typically occurs, while area 3 has been considered as a control area on which the coastal upwelling has no effect. In each area, mean temperature and salinity in the upper layer $(5-30 \mathrm{~m})$ are estimated.

The main surface circulation features in the Strait of Sicily were evaluated by means of the altimeter products (absolute dynamic topography) produced by Ssalto/Duacs and distributed by Aviso, with support from Cnes (http://www.aviso. oceanobs.com/duacs/). The estimated path of the two main streams (AIS and ATC) of the AW was checked by using salinity profiles collected in the study area. Since both streams are mainly characterized by a salinity minimum $\left(S_{\min }\right)$, for each oceanographic survey, the cores of AIS and ATC were also identified by $S_{\min }$ values at each transect perpendicular to the Sicily coast (e.g. Fig. 5). The circulation pattern (geostrophic velocity field) in the study area was evaluated in the periods of the oceanographic surveys (see Table 1).

\section{Results}

The $\theta-S$ diagram (e.g. Fig. 2 for the 1999 survey) mainly highlights the presence of two highly stratified water masses: fresher AW in the upper layer, and an intermediate westwardflowing salty LIW. A third layer of transitional water masses (tEMDW) with variable hydrological characteristics is also evident. The Ionian surface water (ISW) is recorded only in some stations located east of meridian $15^{\circ} \mathrm{E}$, while, in the northwestern part of the study area, the western intermediate water (WIW) is observed. 


\subsection{The surface layer}

The analysis of the data set, mainly constituted by CTD profiles acquired in the period between the end of June and July (except in 1999; see Table 1), confirms a high variability of the surface layer $(0-200 \mathrm{~m})$ in terms of temperature, salinity and density (Table 2), due to the complex circulation of surface water. The presence of a water mass of Atlantic origin is highlighted by the minimum in the vertical salinity profiles $\left(S_{\min }\right)$. The average value of salinity minimum varied between 37.22, observed during the survey "Bansic07", and 37.86, recorded in the survey "Bansic12" (Fig. 3a). Potential temperature at a depth of minimum salinity varied between 17.36 and $20.34^{\circ} \mathrm{C}$, which were the mean values estimated during the oceanographic surveys "Bansic13" and "Bansic08", respectively (Fig. 3b).

The analysis of the hydrological data set evidences the presence of transition water positioned between AW and LIW: the WIW (Fig. 2). During the surveys in the Strait of Sicily, this has been recognized with a clear signal in some stations in the northwestern part of the study area during the 1999, 2005, 2006, 2009, 2010 and 2013 surveys. Here, the WIW is characterized by a potential temperature between 13.95 and $14.2{ }^{\circ} \mathrm{C}$, a salinity in the range $38-38.6$ and density lower than $28.8 \mathrm{~kg} \mathrm{~m}^{-3}$; it forms a portion of the water column positioned between a 100 and $200 \mathrm{~m}$ depth.

Mean values of $S_{\min }$ and $T_{S_{\min }}$ show large inter-annual variability (Fig. 3). From 1998 to 2007, mean values of $S_{\min }$ were characterized by moderate variability around 37.4. In the period 2007-2012, a positive trend was evident up to a mean value of about 37.7. The trend, reported in Fig. 3, slightly changes if data from the western Ionian Sea (longitudes $15-15.5^{\circ} \mathrm{E}$ ) is included.

$S_{\min }$ values are significantly correlated $(r=0.72$, $p<0.05)$ with mean salinity values estimated in the upper layer $(0-200 \mathrm{~m})$ of the water column (Table 2), while there is no correlation between $T_{S_{\min }}$ and mean temperature in the same upper layer. This latter result is likely due to the effects of coastal upwelling, strongly influencing the temperature field along the coast of southern Sicily (Table 3).

A Kruskal-Wallis (K-W) ANOVA test (Conover, 1999) was carried out to verify whether significant differences exist among the three areas evidenced in Fig. 1, and to highlight the effects of upwelling events in the analysed period. K-W ANOVA results showed that significant differences exist among identified areas in terms of both salinity $\left(H_{(2, N=48)}=14.52 ; p<0.05\right)$ and temperature $\left(H_{(2, N=48)}=\right.$ $27.23 ; p<0.05)$. Specifically, post-hoc test highlights that area 1 and area 2 are not significantly different, while area 3 is characterized by significantly higher temperature and lower salinity values (Fig. 4) than area 1 and area 2. Furthermore, temperature values related to area 3 show lower variability than in area 1 and area 2 , while in terms of salinity area 1 and area 2 are characterized by lower variability than area 3. Such a different variability in terms of salinity and
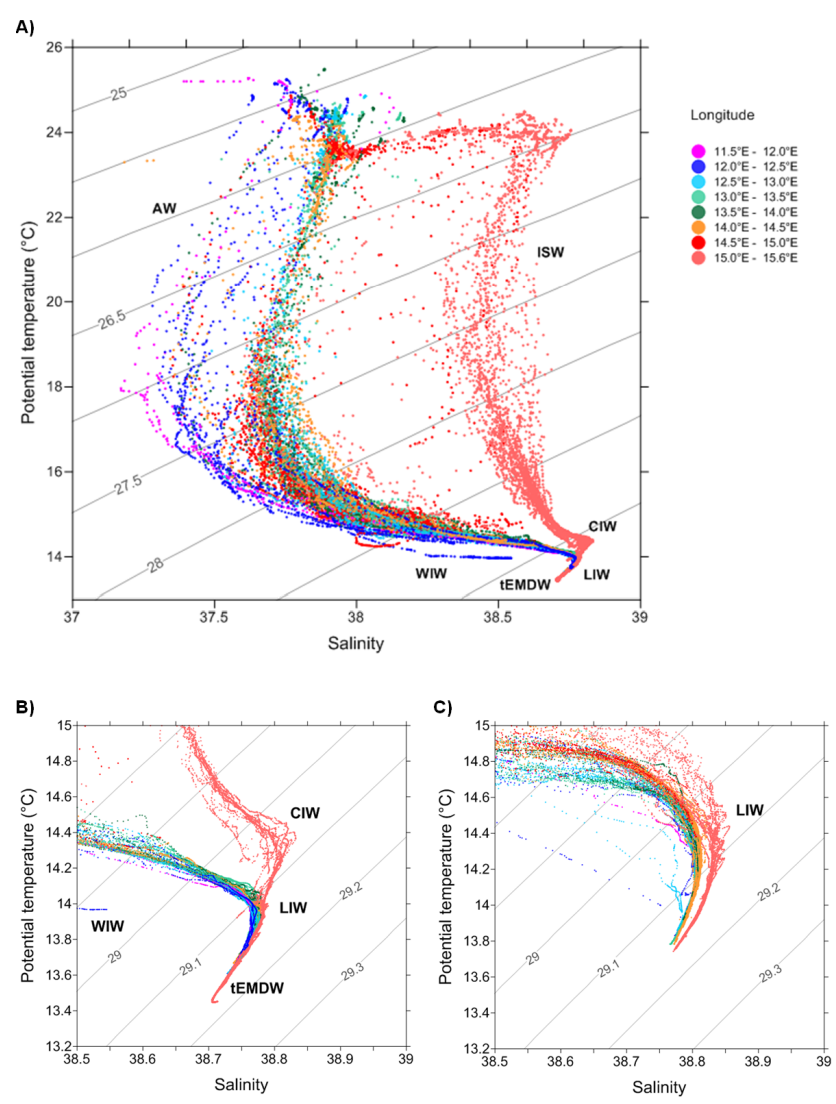

Figure 2. (a) $\theta-S$ diagram for the survey Juvenile99 (Strait of Sicily and west Ionian Sea). The colors refer to longitude of the stations. $\theta-S$ diagrams in the salinity range 38.5-39 for the survey Juvenile99 (b) and Ansic04 (c).

temperature could reflect the variability of the AIS path in the area 3. The outlier value identified for temperature in area 1 is related to the year 1999, when the survey was carried out during Autumn (Fig. 4). During summer 2012 the observed anomalous salinity values in area 1 and area 2 are linked to the strong upwelling event affecting the whole coastal area along the southern coast of Sicily (see Fig. 7).

The geostrophic velocity field, evaluated for the CMED by means of the AVISO altimeter products, permitted the highlighting of the two main streams of AW: ATC and AIS (Fig. 5). The salinity profiles along transects perpendicular to the Sicily coast permitted checking the path of both streams in the study area (e.g. Fig. 6). The pattern of salinity minimum (Fig. 7) shows a variety of segmented structures, also confirming the complex circulation of surface water.

The interpretation of the density interfaces (not shown) and of geostrophic currents (Fig. 5) in the study period, highlights the presence of alternating cyclonic and anticyclonic structures along the central part of the southern coast of Sicily $\left(13.5-14^{\circ} \mathrm{E}\right)$. The anticyclonic pattern operates a push towards higher latitudes of the AW, favouring the entry of fresh water along the Sicilian coast (surveys 1998, 2002, 
Table 2. Number of stations for each layer and average values and standard deviations (SDs) of salinity, potential temperature $\left({ }^{\circ} \mathrm{C}\right)$ and potential density $\left(\mathrm{kg} \mathrm{m}^{-3}\right)$ for each survey. In the layer 0-200 $\mathrm{m}$ are also included transitional waters.

\begin{tabular}{|c|c|c|c|c|c|c|c|c|c|c|c|c|}
\hline \multirow[b]{2}{*}{ Cruise } & \multicolumn{4}{|c|}{ Layer 0-200 m } & \multicolumn{4}{|c|}{ Layer $200-500 \mathrm{~m}$} & \multicolumn{4}{|c|}{ Layer 500-bottom } \\
\hline & $\begin{array}{l}\text { Number of } \\
\text { stations }\end{array}$ & Salinity & $\begin{array}{l}\text { Pot. temp. } \\
{ }^{\circ} \mathrm{C}\end{array}$ & $\begin{array}{l}\text { Density } \\
\mathrm{kg} \mathrm{m}^{-3}\end{array}$ & $\begin{array}{l}\text { Number of } \\
\text { stations }\end{array}$ & Salinity & $\begin{array}{l}\text { Pot. temp. } \\
{ }^{\circ} \mathrm{C}\end{array}$ & $\begin{array}{l}\text { Density } \\
\mathrm{kg} \mathrm{m}^{-3}\end{array}$ & $\begin{array}{l}\text { Number of } \\
\text { stations }\end{array}$ & Salinity & $\begin{array}{l}\text { Pot. temp. } \\
{ }^{\circ} \mathrm{C}\end{array}$ & $\begin{array}{l}\text { Density } \\
\mathrm{kg} \mathrm{m}^{-3}\end{array}$ \\
\hline Mago98 & 170 & 37.982 & 16.15 & 27.985 & 45 & 38.730 & 13.91 & 29.094 & 26 & 38.735 & 13.68 & 29.147 \\
\hline $\mathrm{SD}$ & & 0.437 & 2.36 & 0.870 & & 0.040 & 0.14 & 0.057 & & 0.006 & 0.05 & 0.005 \\
\hline Juvenile99 & 185 & 38.246 & 16.95 & 27.969 & 70 & 38.767 & 13.95 & 29.113 & 33 & 38.739 & 13.65 & 29.155 \\
\hline SD & & 0.393 & 3.55 & 1.074 & & 0.017 & 0.1 & 0.031 & & 0.018 & 0.11 & 0.009 \\
\hline Ansic00 & 303 & 38.172 & 15.92 & 28.174 & 85 & 38.776 & 14.00 & 29.109 & 16 & 38.762 & 13.73 & 29.157 \\
\hline SD & & 0.43 & 2.51 & 0.868 & & 0.001 & 0.11 & 0.031 & & 0.007 & 0.05 & 0.005 \\
\hline Ansic01 & 421 & 38.241 & 16.76 & 28.01 & 96 & 38.785 & 14.09 & 29.096 & 42 & 38.769 & 13.78 & 29.151 \\
\hline $\mathrm{SD}$ & & 0.444 & 3.10 & 0.994 & & 0.032 & 0.21 & 0.057 & & 0.01 & 0.07 & 0.008 \\
\hline Ansic02 & 275 & 38.139 & 16.79 & 27.943 & 94 & 38.788 & 14.08 & 29.102 & 42 & 38.763 & 13.75 & 29.153 \\
\hline SD & & 0.519 & 2.93 & 1.033 & & 0.013 & 0.17 & 0.038 & & 0.018 & 0.15 & 0.018 \\
\hline Ansic03 & 286 & 38.273 & 16.75 & 28.034 & 77 & 38.79 & 14.21 & 29.074 & 44 & 38.776 & 13.91 & 29.129 \\
\hline SD & & 0.455 & 3.69 & 1.184 & & 0.017 & 0.17 & 0.041 & & 0.011 & 0.07 & 0.009 \\
\hline Ansic04 & 234 & 38.147 & 16.20 & 28.008 & 84 & 38.803 & 14.15 & 29.098 & 42 & 38.785 & 13.89 & 29.139 \\
\hline $\mathrm{SD}$ & & 0.575 & 2.53 & 1.055 & & 0.013 & 0.17 & 0.039 & & 0.009 & 0.08 & 0.011 \\
\hline Bansic05 & 220 & 38.146 & 16.01 & 28.13 & 72 & 38.805 & 14.1 & 29.121 & 40 & 38.785 & 13.84 & 29.151 \\
\hline $\mathrm{SD}$ & & 0.487 & 3.00 & 0.973 & & 0.018 & 0.15 & 0.031 & & 0.009 & 0.08 & 0.01 \\
\hline Bansic06 & 242 & 38.189 & 17.09 & 27.882 & 51 & 38.793 & 14.01 & 29.119 & 23 & 38.764 & 13.8 & 29.152 \\
\hline $\mathrm{SD}$ & & 0.408 & 3.84 & 1.147 & & 0.03 & 0.25 & 0.037 & & 0.013 & 0.09 & 0.008 \\
\hline Bansic07 & 209 & 38.007 & 16.82 & 27.843 & 57 & 38.824 & 14.18 & 29.107 & 27 & 38.796 & 13.88 & 29.151 \\
\hline $\mathrm{SD}$ & & 0.559 & 2.6 & 0.988 & & 0.024 & 0.25 & 0.078 & & 0.015 & 0.05 & 0.012 \\
\hline Bansic08 & 153 & 38.031 & 16.59 & 27.919 & 49 & 38.807 & 14.23 & 29.094 & 27 & 38.773 & 13.99 & 29.133 \\
\hline $\mathrm{SD}$ & & 0.511 & 2.54 & 0.952 & & 0.019 & 0.18 & 0.037 & & 0.012 & 0.04 & 0.007 \\
\hline Bansic09 & 170 & 38.106 & 15.99 & 28.111 & 58 & 38.797 & 14.08 & 29.107 & 32 & 38.772 & 13.83 & 29.144 \\
\hline $\mathrm{SD}$ & & 0.516 & 2.5 & 0.915 & & 0.018 & 0.17 & 0.036 & & 0.009 & 0.06 & 0.005 \\
\hline Bansic10 & 236 & 38.005 & 16.07 & 27.934 & 79 & 38.792 & 14.06 & 29.106 & 29 & 38.78 & 13.84 & 29.146 \\
\hline $\mathrm{SD}$ & & 0.472 & 2.18 & 0.915 & & 0.032 & 0.1 & 0.041 & & 0.009 & 0.06 & 0.006 \\
\hline Bansic11 & 157 & 38.17 & 16.06 & 27.992 & 52 & 38.781 & 14.16 & 29.078 & 25 & 38.792 & 13.87 & 29.148 \\
\hline $\mathrm{SD}$ & & 0.334 & 2.72 & 1.024 & & 0.055 & 0.14 & 0.063 & & 0.008 & 0.06 & 0.007 \\
\hline Bansic12 & 202 & 38.393 & 16.72 & 28.143 & 56 & 38.824 & 14.27 & 29.087 & 36 & 38.788 & 13.91 & 29.137 \\
\hline $\mathrm{SD}$ & & 0.39 & 3.34 & 1.052 & & 0.023 & 0.20 & 0.041 & & 0.014 & 0.10 & 0.010 \\
\hline Bansic13 & 235 & 38.080 & 16.67 & 27.924 & 50 & 38.829 & 14.24 & 29.097 & 25 & 38.800 & 13.93 & 29.142 \\
\hline SD & & 0.438 & 2.75 & 0.886 & & 0.015 & 0.19 & 0.036 & & 0.012 & 0.09 & 0.009 \\
\hline
\end{tabular}

Table 3. Mean temperature and salinity in the coastal upwelling region (areas 1 and 2) and in the control one (area 3).

\begin{tabular}{|c|c|c|c|c|c|c|}
\hline \multirow[b]{2}{*}{ Cruise } & \multicolumn{2}{|l|}{ Area 1} & \multicolumn{2}{|l|}{ Area 2} & \multicolumn{2}{|l|}{ Area 3} \\
\hline & Temperature $\left({ }^{\circ} \mathrm{C}\right)$ & Salinity & Temperature $\left({ }^{\circ} \mathrm{C}\right)$ & Salinity & Temperature $\left({ }^{\circ} \mathrm{C}\right)$ & Salinity \\
\hline Mago98 & 17.9 & 37.751 & 19.6 & 37.467 & 21.6 & 37.432 \\
\hline Juvenile99 & 22.1 & 37.830 & 21.4 & 37.836 & 23.1 & 37.865 \\
\hline Ansic00 & 17.1 & 37.799 & 16.8 & 37.817 & 21.6 & 37.480 \\
\hline Ansic01 & 19.9 & 37.577 & 19.6 & 37.641 & 19.8 & 37.533 \\
\hline Ansic02 & 17.7 & 37.778 & 19.0 & 37.629 & 22.8 & 37.345 \\
\hline Ansic03 & 18.2 & 37.939 & 19.8 & 37.903 & 20.7 & 37.624 \\
\hline Ansic04 & 16.1 & 38.008 & 17.4 & 37.834 & 20.4 & 37.373 \\
\hline Bansic05 & 16.8 & 37.816 & 17.5 & 37.701 & 20.6 & 37.608 \\
\hline Bansic06 & 18.7 & 37.719 & 18.3 & 37.693 & 21.5 & 37.736 \\
\hline Bansic07 & 18.9 & 37.527 & 18.8 & 37.512 & 21.5 & 37.312 \\
\hline Bansic08 & 17.3 & 37.727 & 19.2 & 37.582 & 22.1 & 37.422 \\
\hline Bansic09 & 16.5 & 37.813 & 17.1 & 37.635 & 20.4 & 37.485 \\
\hline Bansic10 & 16.5 & 37.821 & 18.4 & 37.620 & 20.3 & 37.479 \\
\hline Bansic11 & 18.8 & 37.751 & 19.7 & 37.764 & 21.8 & 37.700 \\
\hline Bansic12 & 18.3 & 38.354 & 19.4 & 38.372 & 21.7 & 37.743 \\
\hline Bansic13 & 16.0 & 37.865 & 16.6 & 37.851 & 21.4 & 37.715 \\
\hline
\end{tabular}




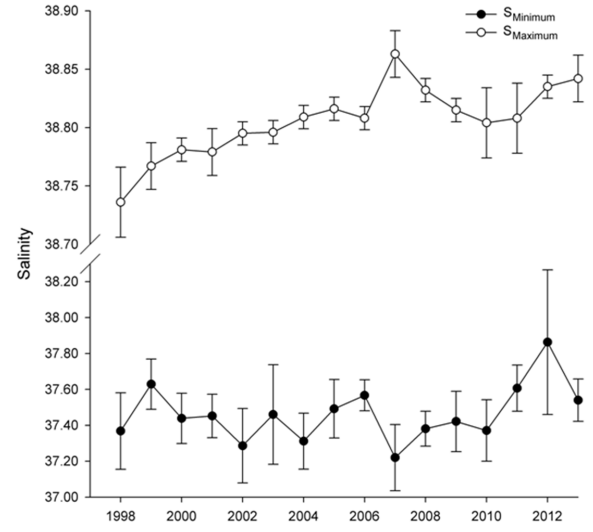

(a) Surveys

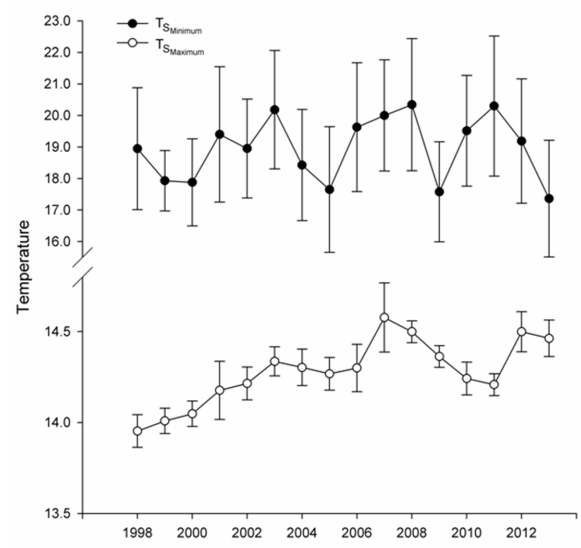

(b) Survey

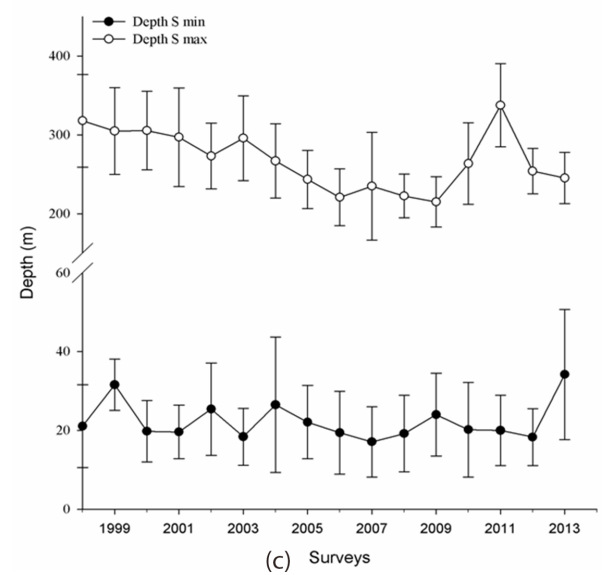

Figure 3. (a) Mean values of salinity minimum and salinity maximum recorded in the period 1998-2013. (b) Mean potential temperature and (c) mean depth recorded at depth of salinity minimum and salinity maximum.

2004, 2005, 2008 and 2010 in Fig. 5). Nevertheless, in some years, even though such an anticyclonic pattern is present, fresh AW does not reach the Sicilian coasts (Figs. 5 and 7). The horizontal salinity patterns also show the presence of a thermohaline front east of the Strait of Sicily $\left(\sim 15^{\circ} \mathrm{E}\right)$,
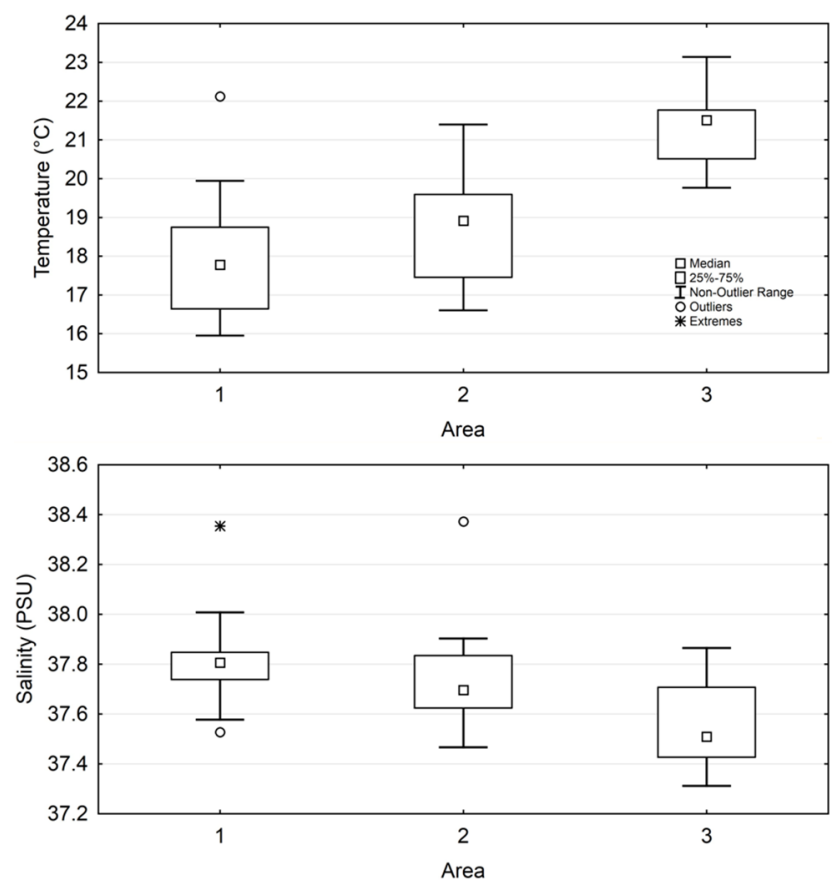

Figure 4. Box plot of temperature and salinity in the layer $5-30 \mathrm{~m}$ for the upwelling areas (1 and 2) and the control area (3), identified in Fig. 1.

which indicates a sort of physical barrier to the dynamics of surface circulation (Fig. 7).

\subsection{The intermediate layer}

The $\theta-S$ diagram (e.g. in Fig. 2) highlights the presence of an intermediate layer $(200-500 \mathrm{~m})$ of westward salty water of eastern origin. In the eastern part of the area, east of $15^{\circ} \mathrm{E}$, the presence of CIW was recorded during the 1999 , 2000, 2001, 2006, 2012 and 2013 surveys (not shown). CIW and LIW are identified in the $\theta-S$ diagram (e.g. Fig. 2b), due to the deviation towards higher values of salinity. In the eastern part of the Strait of Sicily, the CIW is characterized by slightly higher levels of salinity, compared to LIW, with a potential temperature of $\theta=14.5-15^{\circ} \mathrm{C}$ and a density of $\sigma<29.1 \mathrm{~kg} \mathrm{~m}^{-3}$.

In the present study, the maximum-salinity $\left(S_{\max }\right)$ value is interpreted as a signature of LIW core in the study area; it is located between 200 and $350 \mathrm{~m}$ (Fig. 3c). Between the years 1998 and 2013, a general increase of $S_{\max }$ values, especially in 2007 and 2013, has been recorded (Fig. 3a), while temperature $\left(T_{S_{\max }}\right)$ and depth have more variability than trend (Fig. 3). Mean values of $S_{\max }$ and $T_{S_{\max }}$ are in the ranges 38.73-38.86 and $13.95-14.57^{\circ} \mathrm{C}$ (Fig. 3), respectively. Additional information on the LIW in the Strait of Sicily can be derived from the analysis of $\theta-S$ diagrams in the intermediate layer for the station 945 (see Fig. 8). A positive trend in salinity of LIW is evident in the period 1998-2007, except 


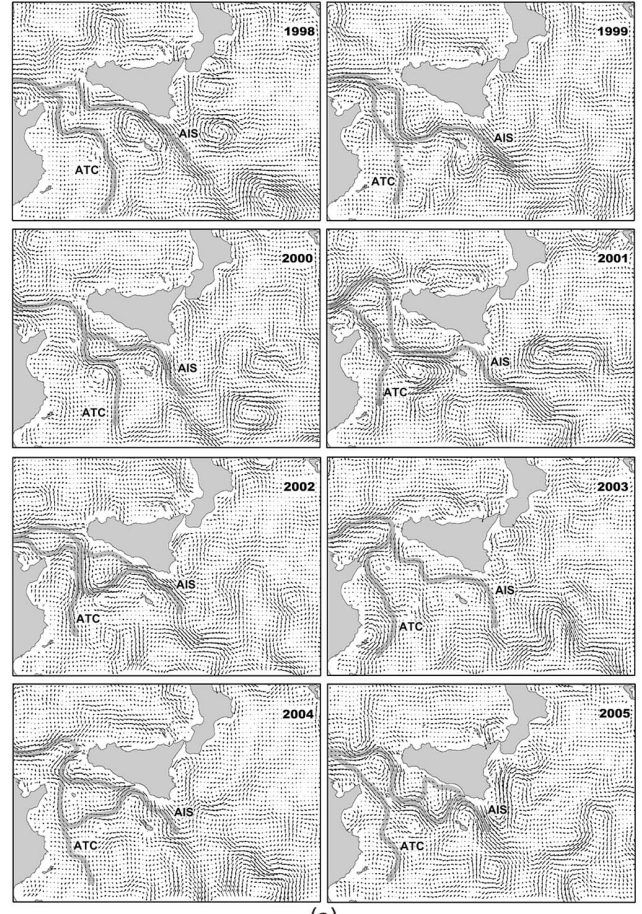

(a)
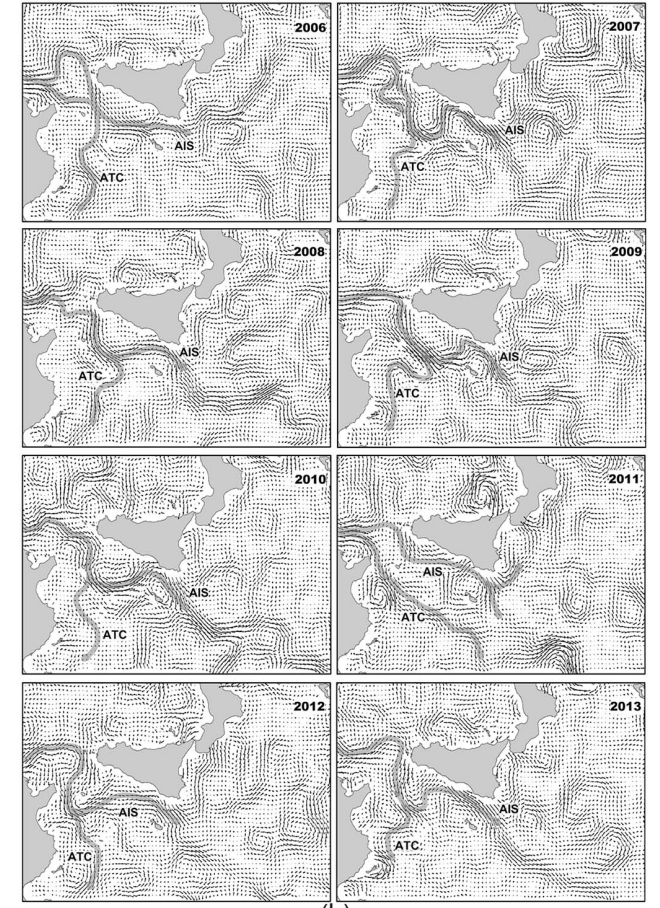

(b)

Figure 5. Mean geostrophic velocity field (absolute dynamic topography by Aviso) estimated in the period of each survey. The patterns of the main circulation streams (ATC and AIS) are evaluated by the AVISO altimeter products.
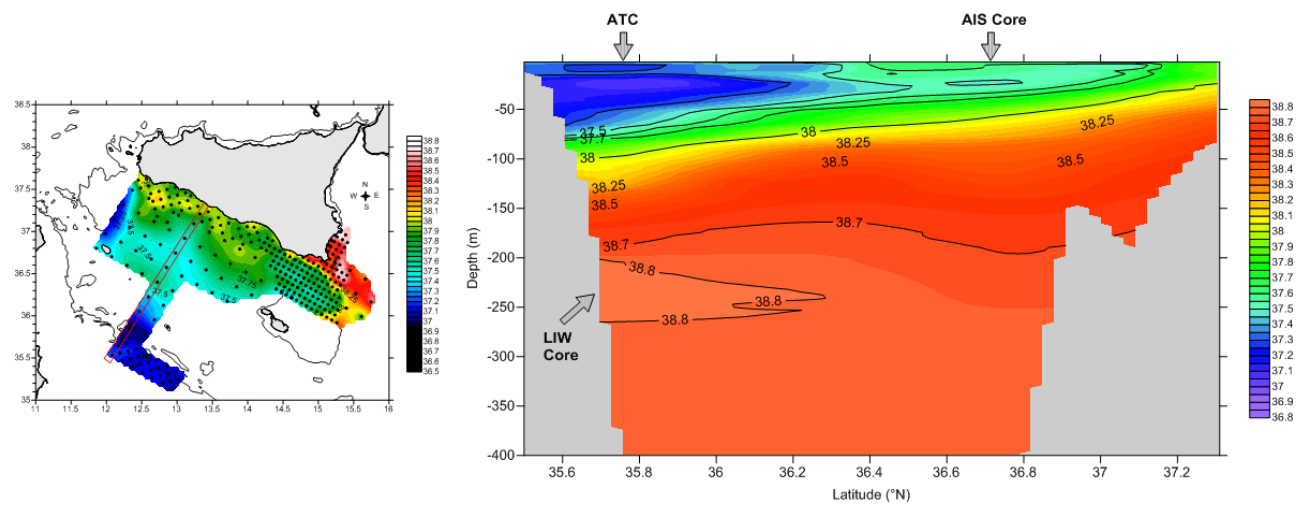

Figure 6. Surface-salinity map, estimated in the oceanographic survey "Ansic 03" (left side). Salinity section (right side) and position of the main water masses along the selected transect (red box on the map) $250 \mathrm{~km}$ long .

for 2006, when a slight decrease in salinity was recorded (Fig. 8a). Afterwards, in the period 2007-2011, a decrease in salinity can be observed (Fig. 8b). Starting from 2011, the system seems to switch towards higher salinity levels up to 2013. Salinity and potential temperature for the period 1998 2013 (Table 2), in the intermediate layer (200-500 m), are positively correlated with high values of Spearman's correlation coefficient $(r=0.71, p<0.05)$.

\subsection{The deepest layer}

Even though the central basin, occupying a significant portion of the Strait, has a mean depth of about $800 \mathrm{~m}$, it can be deeper in several trenches, reaching $1700 \mathrm{~m}$. In deeper layers, sea water displays lower temperatures and salinities than the LIW. In the Strait of Sicily, the tEMDW is characterized by a temperature minimum of $13.63^{\circ} \mathrm{C}$, a salinity of 38.73 and a density of $29.15 \mathrm{~kg} \mathrm{~m}^{-3}$. In this bottom layer, both potential temperature and salinity showed a general increase in the period 1998-2013; mean temperature ranged from 13.65 to $13.99^{\circ} \mathrm{C}$, while mean salinity ranged from 38.73 to 38.8 


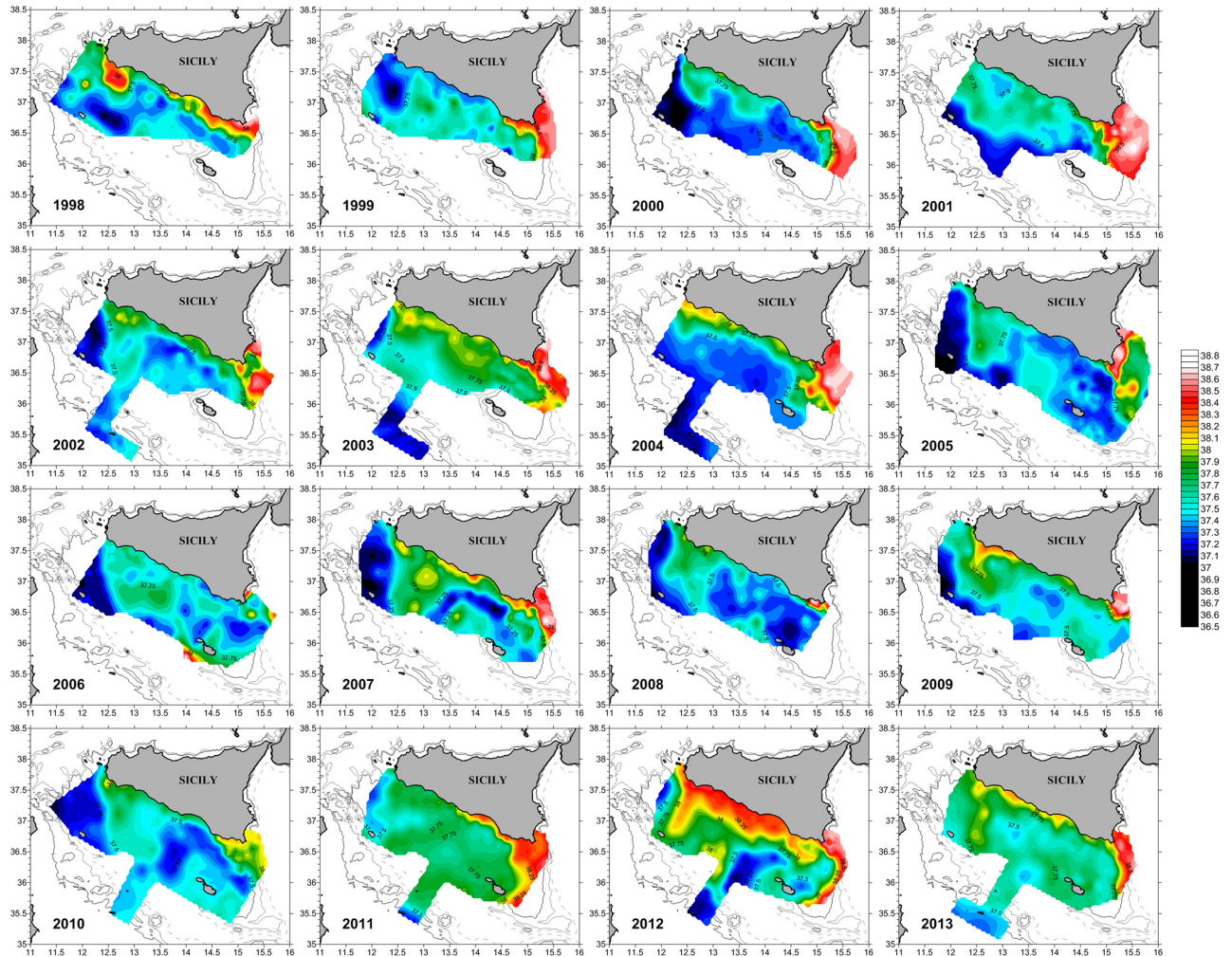

Figure 7. Horizontal distribution of the minimum salinity $\left(S_{\min }\right)$ in the Strait of Sicily and western Ionian Sea in the period $1998-2013$.
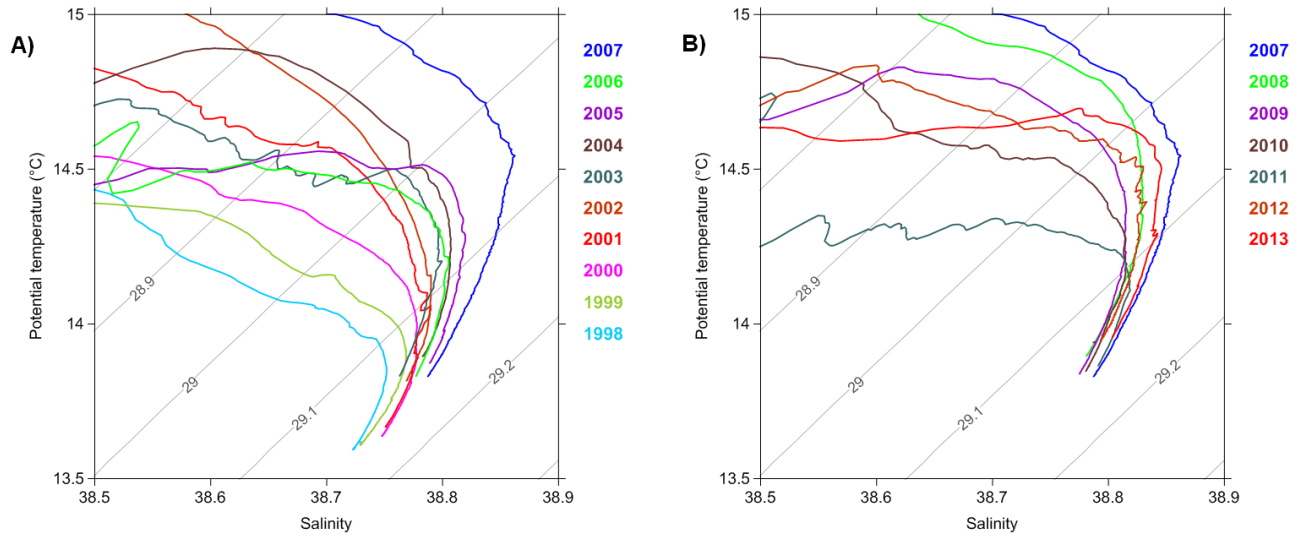

Figure 8. $\Theta-S$ diagrams of the intermediate layer in the Strait of Sicily (Station 945): (a) period 1998-2007 and (b) period $2007-2013$.

(Table 2). Salinity and potential temperature in the period 1998-2013 show high values of Spearman's correlation coefficient ( $r=0.81, p<0.05)$. This coefficient increases up to a maximum of 0.9 if the correlation is performed over the years 1998-2007.

The entire water column has been characterized by an increase in salinity since 1998; especially between 2004 and 2005 , there was a greater spread of salinity throughout the water column. The Hovmöller diagrams for the stations 945 and G605 (Fig. 9) show wide variation of density between 1998 and 2013. Unfortunately, the CTD profile in the station
945 was not always collected until the maximum depth (bottom); since 2003, the maximum depth was about $600 \mathrm{~m}$.

The analysis of Fig. 9 evidences that the isopycnal $29.15 \mathrm{~kg} \mathrm{~m}^{-3}$ has a depth in the range $500-700 \mathrm{~m}$ in the years 2000, 2005 and 2010, while it drops below $1000 \mathrm{~m}$ in the years 2004, 2008 and 2012. 

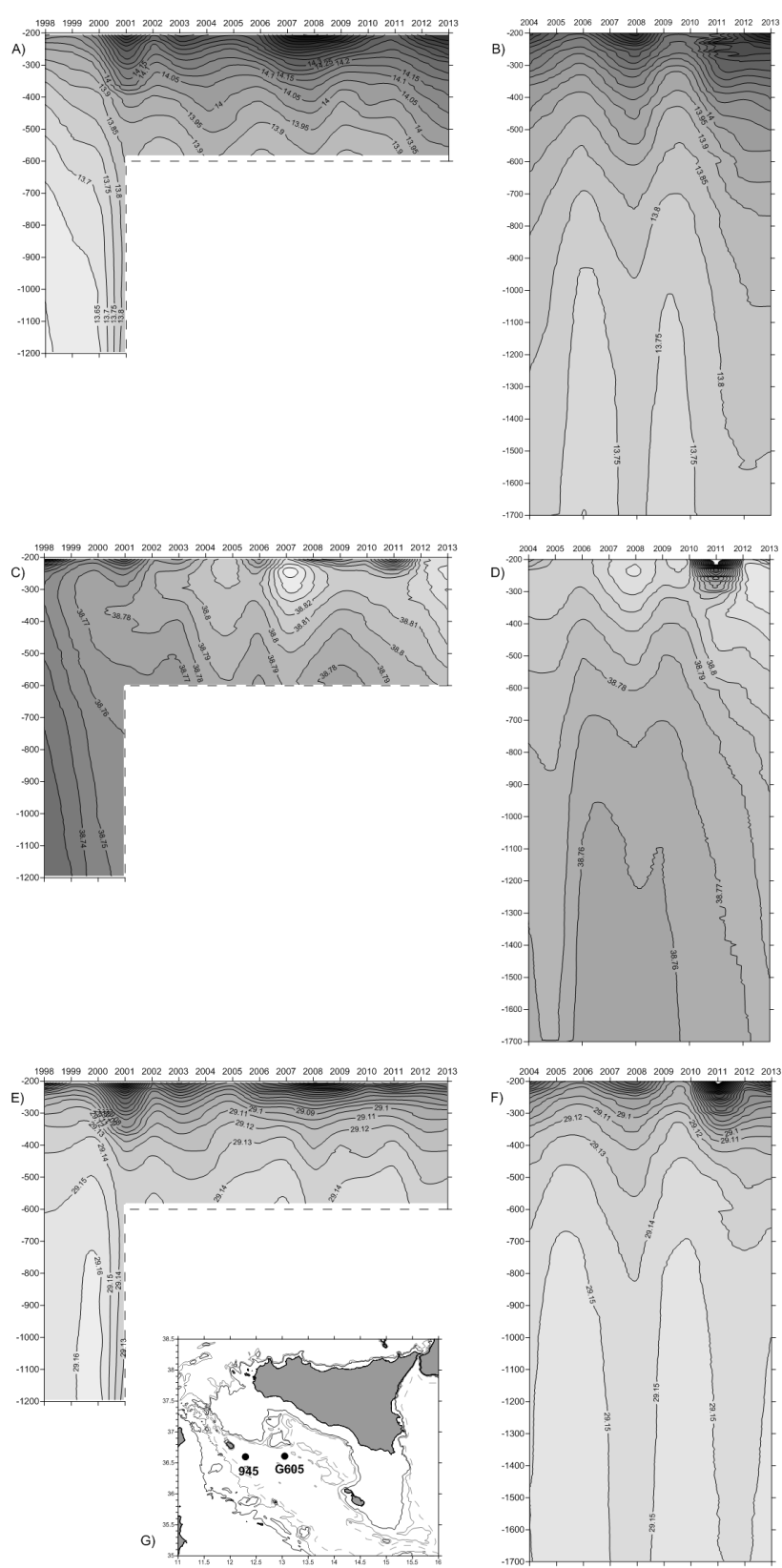

Figure 9. Hovmöller diagrams of potential temperature (a), salinity (c) and potential density (e) in the layer $200-1200 \mathrm{~m}$ in the station $945(1200 \mathrm{~m})$ for the period 1998-2013. Hovmöller diagrams of potential temperature (b), salinity (d) and potential density (f) in the layer $200-1700 \mathrm{~m}$ in the station G605 $(1700 \mathrm{~m})$ for the period 2003-2013. (e) Map with the position of the stations 945 and G605.

\section{Discussion}

The surface layer $(0-200 \mathrm{~m})$ in the CMED is known to be characterized by both intrannual and inter-annual high variability (Gasparini et al., 2005; Ben Ismail et al., 2012). The time series of the salinity-minimum pattern and of geostrophic velocity fields confirm the complex circula- tion of surface water, which, in this area, is dominated by mesoscale processes (Lermusiaux and Robinson, 2001; Sammari et al., 1999; Ben Ismail et al., 2012). Our data set highlights significant variabilities in size, position and shape of the vortices, as well as the relative strength and the location of the AIS. In particular, the data confirm the permanent character of the Adventure-Bank Vortex (ABV) (Lermusiaux and Robinson, 2001) and of temperature and salinity fronts of the Ionian slope. Such thermohaline fronts, positioned in the southeastern part of the study area, are known to be able to promote concentration processes for small organisms in the upper water layer (Basilone et al., 2013; Bonanno et al., 2006).

The observed variability of surface circulation at sub-basin scale highlights that the "Maltese Channel Crest", a summer mesoscale feature located northwest of Malta (Robinson et al., 1999) does not seem to be a permanent feature of the area, in agreement with previous studies (Béranger et al., 2004; Sorgente et al., 2011). The Ionian Shelf-Break Vortex (IBV) (Robinson et al., 1999) is part of the cyclonic circulation of the AIS in the easternmost part of the study area. Due to the sampling design coverage, in some surveys, CTD data were not collected on this vortex, even though the geostrophic velocity fields seem to suggest a permanent character of the IBV.

The analysed data set highlights that both AIS and ATC are permanent features of the area. Even though the sampling design did not permit covering the whole path of both streams, the AIS seems to be more intense than ATC in the summer and typically characterized by high spatial variability, as also reported by Garcia Lafuente et al. (2005). ATC was partially recognized in the southern part of the central Strait of Sicily.

Upwelling phenomenon along the southern coast of Sicily is a persistent feature of the area, as demonstrated by the collected CTD data set. One of the causes of this phenomenon is the inertia of the isopycnal domes of the AIS meanders and cyclonic vortices (Robinson et al., 1999). Westerly winds may reinforce coastal upwelling (wind-driven upwelling), while southerly winds may temporarily hide the upwelling effects from satellite observation.

For the first time in this area, the presence of WIW is evidenced. This water mass is generated during the winter convection period in the northern area of the western Mediterranean Basin, as a result of surface cooling of the AW and mixing processes with LIW below (Conan and Millot, 1995; Gasparini et al., 1999; Ben Ismail et al., 2012). Generally, WIW forms a portion of the water column positioned between 100 and $200 \mathrm{~m}$ depth with the same flow direction as the AW (Millot, 1999). Intermittent signal of the WIW in the Sicilian Channel has also been reported by Sammari et al. (1999), Lermusiaux and Robinson (2001) and Ben Ismail et al. (2012).

Our data highlight the intermittent presence of WIW in our study area $\left(12.235^{\circ} \mathrm{E}, 37.705^{\circ} \mathrm{N}\right)$ in near-coastal stations 


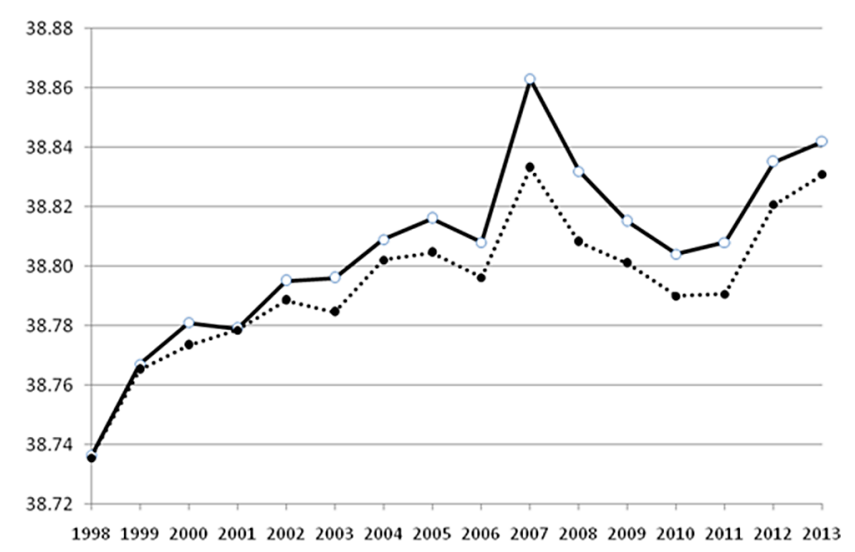

Figure 10. Mean $S_{\max }$ values (continuous line) and mean salinity (dotted line) in the density range $29.0-29.12 \mathrm{~kg} \mathrm{~m}^{-3}$.

and not in all the surveys, suggesting an expansion of WIW also in the western coastal waters of Sicily.

Ben Ismail et al. (2012) singled out the presence of the Ionian water between the AW and the top of the LIW in the western side of the Strait of Sicily, with an east-west direction. The analysed data set permits recognition of the Ionian waters in the eastern part of the Strait of Sicily and, in particular, east of the $15^{\circ} \mathrm{E}$ longitude (Fig. 2a). Moving westwards, the ISW signal is less marked, due to mixing with the surrounding waters.

In order to identify the LIW core, many authors use both the classical "core method" and the fairly fuzzy assumptions that the LIW upper and lower limits can be specified from the $\theta$ maximum and $S_{\max }$ (Millot, 2013). In the salinity profiles collected in the Strait of Sicily, $S_{\max }$ value is always evident, at least in the salinity profiles of stations deeper than $200 \mathrm{~m}$, while the presence of a relative maximum in the $\theta$ profile is rare. In agreement with Sparnocchia et al. (1994) and Gasparini et al. (2008), we considered $S_{\max }$ as a signature of the LIW core in the Strait of Sicily.

Taking into consideration one recent paper by Millot (2013) on the Mediterranean waters (MWs), it could be "postulated that the average potential density that is representative of some heat and salt content associated with a given MW (as well as with all MWs) would have to be maintained up to the Strait of Gibraltar ...".

In this case, the author, analysing the 1985-1986 GIBEX data set, proposed a density range of $29.0-29.075 \mathrm{~kg} \mathrm{~m}^{-3}$ for the LIW core.

Nittis and Lascaratos (1998) proposed a slightly different density range for LIW $\left(28.95-29.10 \mathrm{~kg} \mathrm{~m}^{-3}\right)$, the density of the LIW core being $29.05 \mathrm{~kg} \mathrm{~m}^{-3}$ for the eastern Mediterranean Basin.

Astraldi et al. (2002a) evaluated an LIW density in the range $28.95-29.14 \mathrm{~kg} \mathrm{~m}^{-3}$ for the western part of the Strait of Sicily.
Taking all of these studies into account, and mainly the $\theta$ $S$ profiles collected over the whole study period (1998-2013) in the Strait of Sicily, the mean salinity per year in the density range $29.0-29.12 \mathrm{~kg} \mathrm{~m}^{-3}$, where the LIW core is located, has been evaluated (Fig. 10). The good agreement $(r=0.99$, $p<0.05$ ) between the mean (per year) $S_{\max }$ values and the calculated mean salinity in the specified density range permits to use $S_{\max }$ to follow the variability of the LIW core salinity in the Strait of Sicily.

In the eastern part of the area (longitude $>15^{\circ} \mathrm{E}$ ) the presence of Cretan intermediate water (CIW) was observed only in some surveys; possible mixing phenomena between LIW and CIW did not allow us to differentiate between the two water masses in all of the surveys. Differences between the two water masses are not evident within the Strait of Sicily. Recently, Millot (2013) proposed that the intermediate water, formed in all zones of dense-water formation in the Levantine Basin and flowing through the Strait of Sicily, should be renamed the eastern intermediate water (EIW).

$\Theta-S$ plots highlight different patterns in intermediate and deep waters between CTD casts collected east of $15^{\circ} \mathrm{E}$ and the those acquired in the central part of the Strait of Sicily (e.g. Fig. 2c). It is likely that mixing phenomena occur along the EIW path. Once they have reached the Strait, the intermediate and deep waters maintain their physical characteristics along the entire area of the Strait.

Intermediate water of eastern origin enters the Strait of Sicily from the east through the large, relatively deep passage between Malta and Libya (Manzella, 1994; Placenti et al., 2013). The LIW vein core is characterized by a maximum salinity located between 200 and $350 \mathrm{~m}$; inside the central basin of the Sicilian Channel, the westward flow of LIW is observed along the Tunisian slope (e.g. Fig. 6) in agreement with previous studies (Ben Ismail et al., 2014).

A possible hypothesis to explain the alternation of high and low values of salinity in the intermediate water layer in the Strait of Sicily could be linked to the reversal of upperlayer circulation in the central Ionian Sea (BiOS, Gačić et al., 2010, 2013). An anticyclonic circulation in the Ionian Sea favours a more intense spreading of the AW into the Ionian with the weakening of its spreading into the Levantine (Gačić et al., 2011). In contrast, in the case of cyclonic circulation, there is a wider spreading of AW in the eastern basin that produces a dilution of LIW. Therefore, variations in salinity in the Strait of Sicily could be explained in terms of the thermohaline variability of native LIW, as proposed also by Gačić et al. (2013). Considering a 10-13-year travel time of the signal from Rhodes Gyre to the Strait of Sicily (Gačić et al., 2013), the increase in salinity recorded in the LIW in the Strait of Sicily over the period 1998-2007 may be connected to the decrease of AW spreading in the Levantine Basin (Gačić et al., 2013) observed between the mid-1980s and mid-1990s. The subsequent cyclonic phase could have caused the salinity decrease in the intermediate waters in the Strait of Sicily, 
starting from 2008. In 2012 and 2013, a further increase in salinity and temperature is observed.

During the mid-1990s, a significant volume of tEMDW is found below the LIW (Sparnocchia et al., 1999), which is the result of mixing between the LIW, the old EMDW and the new EMDW, originated from the EMT (Roether et al., 1996, 2007). These waters display lower temperatures and salinities than the LIW. The LIW and tEMDW exit the Strait of Sicily into the Tyrrhenian Sea as two independent veins adjacent to the western Sicilian slope (Astraldi et al., 2002b). Our data set indicates that, since 1998, an increase in temperature and salinity is recorded in the bottom layer; especially between 2004 and 2005, there was a greater spread of salinity throughout the water column, in agreement with Gačić et al. (2013) and Ben Ismail et al. (2014). The potential temperature shows a positive trend from 1998 to 2005, with maximum values recorded in $2003\left(\theta=13.91^{\circ} \mathrm{C}\right)$. A further phase of maximum spread of salinity in the water column is evident between 2007 and 2008. Specifically, in 2007 , there was the maximum value of salinity (38.8), while the maximum value of potential temperature was recorded in $2008\left(\theta=13.99^{\circ} \mathrm{C}\right)$. In this phase, the bottom layer is characterized by the presence of lighter water. In 2006 and 2009, we found different conditions to those described above. In particular, in 2006, there was an abrupt decrease of potential temperature $\left(\theta=13.76^{\circ} \mathrm{C}\right)$ and salinity (38.76), and simultaneously an increase of density $\left(\sigma<29.152 \mathrm{~kg} \mathrm{~m}^{-3}\right.$ ) (see Fig. 9). These findings indicate the presence of a large volume of tEMDW in the Strait of Sicily, in agreement with Ben Ismail et al. (2014).

Similar reductions in potential temperature and salinity of deeper waters were also observed during the 2009 survey. This result likely suggests the enhancement of the passage of volume of tEMDW also in 2009. After 2009 and until 2013, there was a new salt phase that influenced the entire water column.

\section{Conclusions}

The analysed data set allowed to study the high inter-annual water-mass variability in the Strait of Sicily. The obtained results, supported by a large data set both in terms of area covered (sampling intensity) and time interval, highlighted how the Strait of Sicily is an important site for studying the effects of surface and intermediate water circulation at subbasin scale. The analysis of data permitted the study of the permanent character of the main mesoscale features of surface circulation, while the observed trend of $S_{\max }$ in the intermediate water layer seems to be linked to the circulation of the upper layer in the central Ionian Sea (BiOS).

Although the area of the Strait of Sicily is limited at the east and west by two relatively shallow sills, in some parts bottom depth can reach $1700 \mathrm{~m}$. The acquired CTD profiles in such deeper areas allowed us to study the evolution of the
tEMDW characteristics over the period 1998-2013. The results obtained stressed the importance of a continuous monitoring program of deeper water layer in the Strait of Sicily.

Acknowledgements. The study was mainly supported by the Ufficio Programmazione Operativa of the Consiglio Nazionale delle Ricerche. The FAO MedSudMed Project, funded by the Italian Ministry MIPAAF, and the RITMARE Project, funded by the Italian Ministry MIUR, are thanked for their support in the last oceanographic surveys.

Mr. Emanuele Gentile and Mr. Vincenzo Lubrano, Masters of the R/V Urania, and all of their crew are thanked for their work. All of the participating institutes and scientists who were on board are gratefully acknowledged for their involvement in the work carried out.

Edited by: J. M. Huthnance

\section{References}

Astraldi, M., Gasparini, G. P., Vetrano, A., and Vigudelli, S.: Hydrographic characteristics and interannual variability of water masses in the central Mediterranean: a sensitivity test for longterm changes in the Mediterranean Sea, Deep Sea Res. I, 49, 661-680, 2002a.

Astraldi, M., Conversano, F., Civitarese, G., Gasparini, G. P., Ribera d'Alcalà, M., and Vetrano, A.,: Water mass properties and chemical signatures in the central Mediterranean region, J. Mar. Syst., 33-34, 155-177, 2002b.

Basilone, G., Bonanno, A., Patti B., Mazzola S., Barra M., Cuttitta A., and McBride R.: Spawning site selection by European anchovy (Engraulis encrasicolus) in relation to oceanographic conditions in the Strait of Sicily, Fish. Oceanogr., 22, 309-323, 2013.

Ben Ismail, S., Sammari, C., Gasparini, G. P., Béranger, K., Brahim, M., and Aleya, L.,: Water masses exchanged through the Channel of Sicily: evidence for the presence of new water masses on the Tunisian side of the Channel, Deep Sea Res. I, 63, 65-81, 2012.

Ben Ismail, S., Schroeder, K., Sammari, C., Gasparini, G. P., Borghini, M., and Aleya, L.: Interannual variability of water mass properties in the Tunisia-Sicily Channel, J. Mar. Syst., 135, 14-28, 2014.

Béranger, K., Mortier, L., Gasparini, G. P., Gervasio, L., Astraldi, L., and Crépon, M.: The dynamics of the Sicily Strait: a comprehensive study from observations and models, Deep-Sea Res. II, 51, 411-440, 2004.

Bonanno, A., Goncharov, S., Mazzola, S., Popov, S., Cuttitta, A., Patti, B., Basilone, G., Di Nieri, A., Patti, C., Aronica, S., and Buscaino, G.: Acoustic evaluation of anchovy larvae distribution in relation to oceanography in the Cape Passero area (Strait of Sicily), Chem. Ecol., 22, S265-S273, 2006.

Bonanno, A., Zgozi, S., Cuttitta, A., El Turki, A., Di Nieri, A., Ghmati, H., Basilone, G., Aronica, S., Hamza, M., Barra, M., Genovese, S., Falco, F., Knittweis, L., Mifsud, R., Patti, B., Bahri, T., Giacalone, G., Fontana, I., Tranchida, G., and Mazzola, S.: Influence of environmental variability on anchovy early life stages (Engraulis encrasicolus) in two different areas of the Central Mediterranean Sea, Hydrobiologia, 701, 273-287. doi:10.1007/s10750-012-1285-8, 2013. 
Borzelli, G. L. E., Gačić, M., Cardin, V., and Civitarese, G.: Eastern Mediterranean transient and reversal of the Ionian Sea circulation, Geophys. Res. Lett., 36, L15108, doi:10.1029/2009GL039261, 2009.

Brankart, J. M.: The MODB local quality control, Technical Report, University of Liege, Liege, p. 5., 1994.

Conan, P. and Millot, C.: Variability of the northern current off Marseilles, Western Mediterranean Sea, from February to June 1992, Oceanol. Acta, 18, 193-205, 1995.

Conover, W. J.: Practical Nonparametric Statistics, Third Edition, New York: John Wiley \& Sons, 1999.

Demirov, E. and Pinardi, N.: Simulation of the Mediterranean Sea circulation from 1979 to 1993: Part I, The interannual variability, J. Marine Syst., 33-34, 23-50, doi:10.1016/S09247963(02)00051-9, 2002.

Gačić, M., Borzelli, G. L. E., Civitarese, G., Cardin, V., and Yari, S.: Can internal processes sustain reversals of the ocean upper circulation?: The Ionian Sea example, Geophys. Res. Lett., 37, L09608, doi:10.1029/2010GL043216, 2010.

Gačić, M., Civitarese, G., Eusebi Borzelli, G. L., Kovačević, V., Poulain, P.-M., Theocharis, A., Menna, M., Catucci, A., and Zarokanellos, N.: On the relationship between the decadal oscillations of the Northern Ionian Sea and the salinity distributions in the Eastern Mediterranean, J. Geophys. Res., 116, C12002, doi:10.1029/2011JC007280, 2011.

Gačić, M., Schroeder, K., Civitarese, G., Cosoli, S., Vetrano, A., and Eusebi Borzelli, G. L.: Salinity in the Sicily Channel corroborates the role of the Adriatic-Ionian Bimodal Oscillating System (BiOS) in shaping the decadal variability of the Mediterranean overturning circulation, Ocean Sci., 9, 83-90, doi:10.5194/os-983-2013, 2013.

Garcia Lafuente, J., Vargas, J. M., Criado, F., Garcia, A., Delgado, J., and Mazzola, S.: Assessing the variability of hydrographic processes influencing the life cycle of the Sicilian Channel anchovy, Engraulis encrasicolus, by satellite imagery, Fish. Oceanogr. 14, 32-46, 2005.

Gasparini, G. P., Zodiatis, G., Astraldi, M., Galli, C., and Sparnocchia, S.: Winter Intermediate Water lenses in the Ligurian Sea, J. Mar. Syst., 20, 319-332, 1999.

Gasparini, G. P., Ortona, A., Budillon, G., Astraldi, M., and Sansone, E.: The effect of the Eastern Mediterranean Transient on the hydrographic characteristics in the Strait of Sicily and in the Tyrrhenian Sea, Deep-Sea Res. Pt. I, 52, 915-935, 2005.

Gasparini, G. P., Bonanno, A., Zgozi, S., Basilone, G., Borghini, M., Buscaino, G., Cuttitta, A., Essarbout, N., Mazzola, S., Patti, B., Ramadan, A. B., Schroeder, K., Bahri, T., and Massa, F.: Evidence of a dense water vein along the Libyan continental margin, Ann. Geophys., 26, 1-6, doi:10.5194/angeo-26-1-2008, 2008.

Lermusiaux, P. F. J.: Estimation and study of mesoscale variability in the Strait of Sicily, Dynam. Atmos. Oceans, 29, 255-303, 1999.

Lermusiaux, P. F. J. and Robinson, A. R.: Features of dominant mesoscale variability, circulation patterns and dynamics in the Strait of Sicily, Deep-Sea Res. Pt. I., 48, 1953-1997, 2001.
Manzella, G.: The Seasonal variability of the water masses and transport through the Strait of Sicily, Coastal and Estuarine Studies, 46, 33-45, American Geophysical Union, 1994.

Millot, C.: Circulation in theWestern Mediterranean Sea, J. Marine Syst., 20, 423-442, 1999.

Millot, C.: Levantine Intermediate Water characteristics: an astounding general misunderstanding, Sci. Mar., 77, 217-232, doi:10.3989/scimar.03518.13A, 2013.

Nittis, K. and Lascaratos, A.: Diagnostic and prognostic numerical studies of LIW formation, J. Marine Syst., 18, 179-195, 1998.

Placenti, F., Schroeder, K., Bonanno, A., Zgozi, S., Sprovieri, M., Borghini, M, Rumolo, P., Cerrati, G., Bonomo, S., Genovese, S., Basilone, G., Haddoud, D. A., Patti, B. , El Turki, A., Hamza, M., and Mazzola, S.: Water masses and nutrient distribution in the Gulf of Syrte and between Sicily and Libya, J. Marine Sys., 121-122, 36-46, 2013.

Robinson, A. R., Sellschopp, J., Warn-Varnas, A., Leslie, W. G., Lozano, C. J., Haley, P. J., Anderson, L. A., and Lermusiaux, P. F. J.: The Atlantic Ionian Stream, J. Marine Syst., 20, 129-156, 1999.

Roether, W., Manca, B. B., Klein, B., Bregant, D., Georgopoulos, D., Beitzel, V., Kovacevich, V., and Luchetta, A.: Recent changes in Eastern Mediterranean deep waters, Science 271, 333-335, 1996.

Roether, W., Klein, B., Manca, B. B., Theocaris, A., and Kioroglou, S.: Transient Eastern Mediterranean deep waters in response to massive dense-water output of the Aegean Sea in the 1990s, Prog. Oceanogr., 74, 540-571, 2007.

Sammari, C., Millot, C., Taupier-Letage, I., Stefani, A., and Brahim, M.: Hydrological characteristics in the Tunisian-Sardinia-Sicily area during spring 1995, Deep-Sea Res. Pt. I, 46, 1671-1703, 1999.

Schroeder, K., Taillandier, V., Vetrano, A., and Gasparini, G. P.: The circulation of the Western Mediterranean Sea in spring 2005 as inferred from observations and from model outputs, Deep-Sea Res. Pt. I, 55, 947-965, 2008.

Sorgente, R., Drago, A. F., and Ribotti, A.: Seasonal variability in the Central Mediterranean Sea circulation, Ann. Geophys., 21, 299-322, doi:10.5194/angeo-21-299-2003, 2003.

Sorgente, R., Olita, A., Oddo, P., Fazioli, L., and Ribotti, A.: Numerical simulation and decomposition of kinetic energy, Ocean Sci., 7, 503-519, doi:10.5194/os-7-503-2011, 2011.

Sparnocchia, S., Manzella, G. M. R., and La Violette, P. E.: The Interannual and Seasonal Variability of the MAW and LIW Core Properties in the Western Mediterranean Sea, Coast. Estuar. Stud., 46, 177-194, 1994.

Sparnocchia, S., Gasparini, G. P., Astraldi, M., Borghini, M., and Pistek, P.: Dynamics and mixing of the Eastern Mediterranean outflow in the Tyrrhenian basin, J. Mar. Sys., 20, 301-317, 1999.

Theocharis, A., Klein, B., Nittis, K., and Roether, W.: Evolution and status of the Eastern Mediterranean Transient (1997-1999), J. Mar. Syst., 33-34, 91-116, 2002. 